\title{
Design of Enterprise Information System Architecture with Oracle Architecture Development Process (OADP) Case Study in Vocational High Schools
}

\author{
Muhammad Prakarsa Al Qadr Saleh ${ }^{1, *}$, Sofia Dewi ${ }^{2}$ \\ ${ }^{I}$ Department of Computer Engineering, Piksi Ganesha Polytechnic, Bandung, Indonesia. \\ ${ }^{2}$ Department of Information System, Ma'soem University, Bandung, Indonesia. \\ *Corresponding author email: ras_akuto@yahoo.com
}

\begin{abstract}
The development of information and communication technology has led to increasingly competitive competition among organizations. The management of the organization is required to build and develop a fast, precise and accurate information system (IS) to assist business activities in achieving organizational goals and providing services to stakeholders, especially in relation to data, information, technology and applications. ORACLE Architecture Development Process (OADP) is a method or frame of reference for building an information architecture oriented to business needs. This consists of the data architecture, applications, technology and implementation plans of the architectures that have been created to support business activities in achieving the organization mission. The OADP describes the data architecture, applications and technology required to support the organization business. Vocational High Schools cannot be separated from the needs of business and information architecture. A lot of information is generated from all processes that occur in the Vocational High School environment every day but the existing data management is not efficient because it has not been thoroughly connected. This may take a long time to process past data or calculate future needs because the data management process is still running separately. Because of these cases, the modeling information architecture in an organizational environment is required as a stage in supporting the running of business processes in the organization.
\end{abstract}

Keywords: Information System, ORACLE Architecture Development Process (OADP), Enterprise Information System, Vocational Information System.

\section{Introduction}

The development of information technology today has a lot of influence on all aspects of human life. Information technology is growing faster and this makes an organization must be able to follow its development in order to compete in the business world. Various types of businesses can be run 
by information technology well so that the information needs of an organization can be presented quickly, precisely and accurately, without any limitations in time or distance (Moraes and Cernev, 2020; Attaran, 2004; Sambas et al., 2013). This means that information technology can provide effectiveness and efficiency in carrying out an organization business processes

An organization really needs an information system that can help the operational activities of the organization. The bigger an organization, the more activities that must be performed. This will require a way to build and develop appropriate information systems to assist operational activities, achieving goals and improving the service of the organization. The need for information systems is not only required by organizations whose activities are in the business sector but also applies in other sectors such as in the education sector, one of which is in Vocational High Schools (Suswanto et al., 2018; Andayani ).

The system in the education sector at the levels of Elementary School, Junior High School, Senior High School / Vocational High School and Higher Education that each has its own system character. One of the existing problems is that there is no specific basic framework used as a reference in building architecture (Hadiana, 2016; Guthrie and Clayton, 2010). There is a similar process in each educational environment, including admission, learning, evaluation, graduation and staffing. In this study, the authors focused on the vocational school environment. Other problems in the use of information systems are low activity in supporting on-going business processes. This can happen because the existing system has not been able to support all the required business processes or there is no integration of each system according to the needs. The main problem of the data processing process is the lack of consideration of long-term factors that one system definitely needs another system (Wikusna, 2018). The purpose of this research is to design an information system in the form of a blueprint for application architecture with the hope of supporting business processes in the Vocational High School environment

\section{Methodology}

\subsection{Enterprise Architecture}

Enterprise is a group of people who are arranged for a real purpose to produce a product or provide a service (Gong et al., 2020). Enterprise also means a series of corporation or company as a whole; divisions of a corporation, government organization, a single department, or a network of several organizations that are geographically located and connected to one another by a common purpose.

The second term of enterprise architecture is architecture. Architecture is the design of various types of structures whether they are physical or conceptual, real or fake. If the two words are combined, there will be several definitions.

The definition of enterprise architecture is the process of translating a business vision and strategy into a changing enterprise effectively by acting, communicating, and improving the key principles and models that describe the future of the enterprise and implement these changes (Lakhrouit and Baïna, 2020). 


\subsection{Oracle Architecture Development Process (OADP)}

When developing enterprise architecture for consumers, Oracle applies the Oracle Architecture Development Process (OADP) as shown in figure 1. It is a fast and efficient method focused on creating the future architecture of the institution for information organizations. It is developed using an agile mindset architecture in which all activities and processes are oriented towards business value quickly and repeatedly. This section will provide an overview of how OADP is implemented in the Information architecture domain (Samson and Vergnaud, 2019).

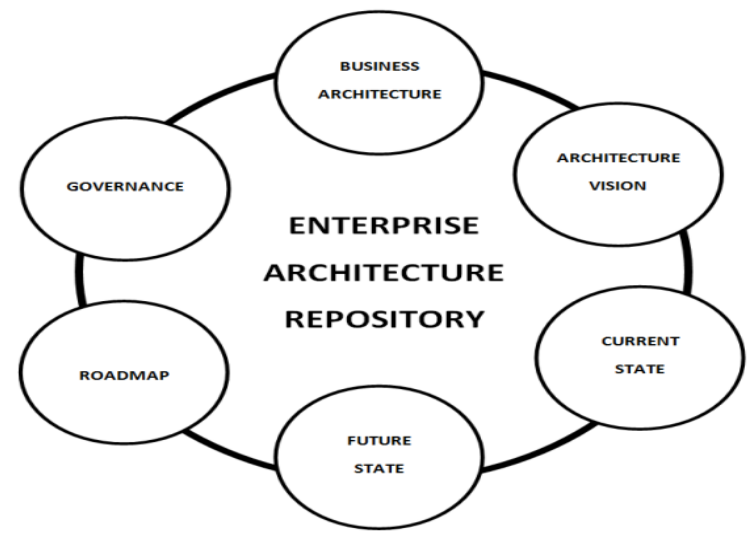

Figure 1. The OADP Framework

a. Business Architecture

This step describes how to understand and evaluate business drivers, operating models, and key processes.

b. Architecture Vision

This step describes how to establish guiding principles and standards for information as a business resource.

c. Current State

This step describes how to identify current challenges and constraints in using data.

d. Future State

This step describes how to develop future information architecture of the institution for maximum scalability, to define terminology, to build consistency and to provide reference architecture utilized throughout the organization.

e. Roadmap

This step describes how to develop a strategic roadmap in implementing the future vision of the institution. 


\section{f. Governance}

This step describes how to build government or institution data in the management information of life cycle.

\subsection{Value Chain}

The value chain model is used to highlight activities in the business. The chain consists of a series of activities which create and build value that can generate added value margins for the organization. Figure 2 shows Porter's value chain which consists of primary and support activities (Kaplinsky, 2000).

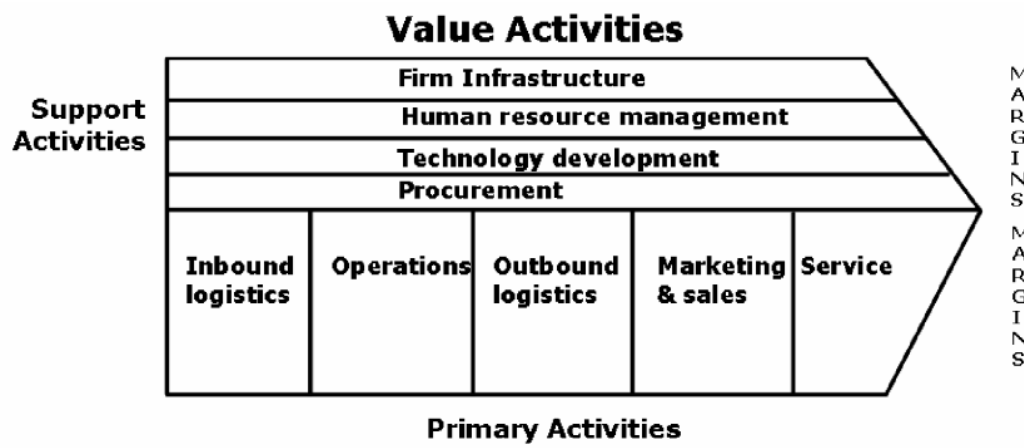

Figure 2. Value Chain

\section{Vocational High School}

Vocational high schools are reviewed based on several opinions of relevant experts and are often used in defining vocational education. Many experts define vocational high school especially presser express the Sixteen Prosser Theorem on Vocational Education. Vocational education is education designed to develop skills, abilities, understanding, attitudes, work habits, and appreciation required by workers in working and making progress in meaningful and productive work (Ozer and Perc, 2020; Rabiman et al., 2020; Yulastri and Hidayat, 2017) In this case, the author takes one of the visions and missions of a vocational high school as follows:

Vision: To be an educational and training institution that has international quality and insight with graduates who have strength in faith and piety, excels in science and technology, excellence, and readiness to compete in facing global challenges.

\section{Mission:}

a. To produce graduates who have a strong faith to God Almighty and have a high awareness of environmental harmony.

b. To produce graduates who have high competence and are ready to compete in both of the national and international labor market.

c. To produce graduates who are able to fill the demands of science and technology as a provision for self-development. 


\section{Results and Discussion}

\subsection{Design of Information Systems Architecture}

In the process of building an Information System, an analysis of data and application design is required, both with standard testing according to the results of data analysis and the functional requirements of the system that have been designed as the basis for information system design. The business process is described in the Value Chain as shown in Figure 3.

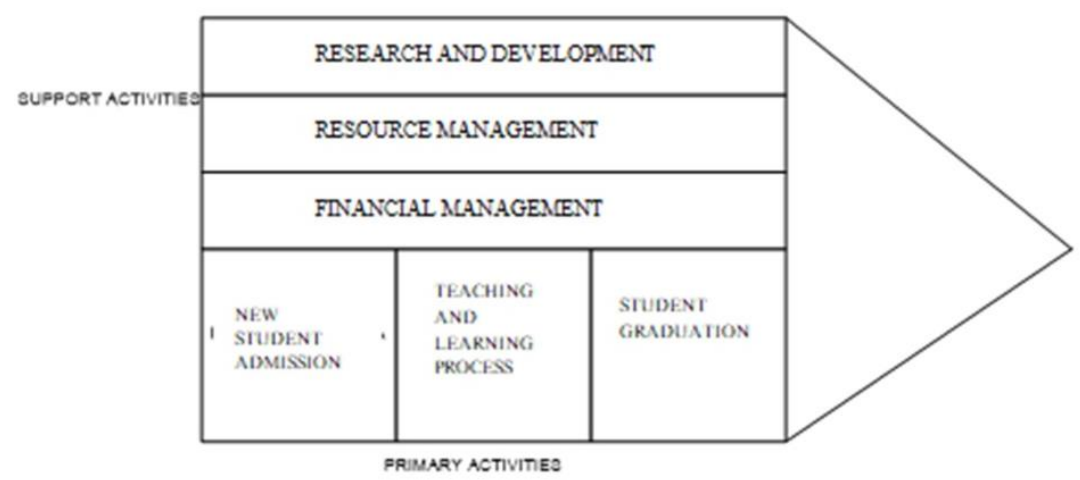

Figure 3. Value Chain

\section{a. Main Activities}

- New Student Admission is an activity of admitting new students in an educational environment.

- Teaching and Learning Process is a learning process activity in an educational environment starting from learning planning such as determining teachers and schedules to implementing learning and learning evaluation.

- Student Graduation is an activity of graduating students after completing the teaching and learning process for 3 years in an educational environment and following the evaluation of the National Examination.

b. Supporting Activites

- Research and Development is a process that is responsible for all research and development activities in the school environment, both technical and non-technical.

- Resource Management is the process of using resources that support existing business processes in the school environment, including facilities, infrastructure, educators and education personnel.

- Financial Management is the process of managing the cash flow in the school environment. 


\subsection{Application Candidates}

To define application candidates, the four stage life cycle tool is used to determine the list of application candidates required to support business processes in an organizational environment that are adjusted to the Value Chain previously discussed. Application candidates are described in Table 1.

Table 1. Application Candidates

\begin{tabular}{|c|c|}
\hline \multicolumn{2}{|c|}{ Application Group 1. New Student Registration System } \\
\hline No & 1 \\
\hline Name & SP2DB \\
\hline Description & $\begin{array}{l}\text { This application has the main function of managing the registration data for } \\
\text { new students who want to continue their education in an organizational } \\
\text { environment. The data entered in the application, some data will become the } \\
\text { master data used as long as the student is involved in the teaching and } \\
\text { learning process in an organizational environment. }\end{array}$ \\
\hline
\end{tabular}

Application Group 2. Net Dashboard

No

Name

Description

\section{2}

\section{SKBM}

This application has the main function as a media provider of information on the learning process and the transparency of the assessment evaluation process and even as information on job vacancies. Students as end users are expected to take advantage of the development of information technology as a dynamic learning medium and teachers can increase their knowledge more often by making the latest learning modules.

Application Group 3. Financial Management

No $\quad 3$

Name SISPP

Description This application has the main function of managing all financial data in an organizational environment. This application will be linked with the Application Program Interface (API) of the Bank to simplify the financial process.

Application Group 3. Resource Management

No

Name

4

Description

\section{MSD}

This application has the main function of managing inventory data and bio data of educators and educational personnel. This application will simplify the process of stock of name and teaching data reporting to the department. 


\subsubsection{Design of Application}

After creating candidate application requirements, according to OADP, the next phase is mapping the application candidates with Use Case and Class Diagram modeling. It is necessary to provide an overview of how the application design will be made to match the business process as previously described. The following is a description of the proposed application design in an organizational environment:

\section{a. New Student Registration Process}

The author designs the new student registration process as shown in Figure 4. The actors involved in the use case are prospective students and the committee of new student admissions. Prospective student's access through the page provided and then fills out the registration to get login access to immediately complete the registration form and upload receipt of payment. The committee of new student admissions has a duty to verify the transfer receipt of registration that has been uploaded by prospective students.

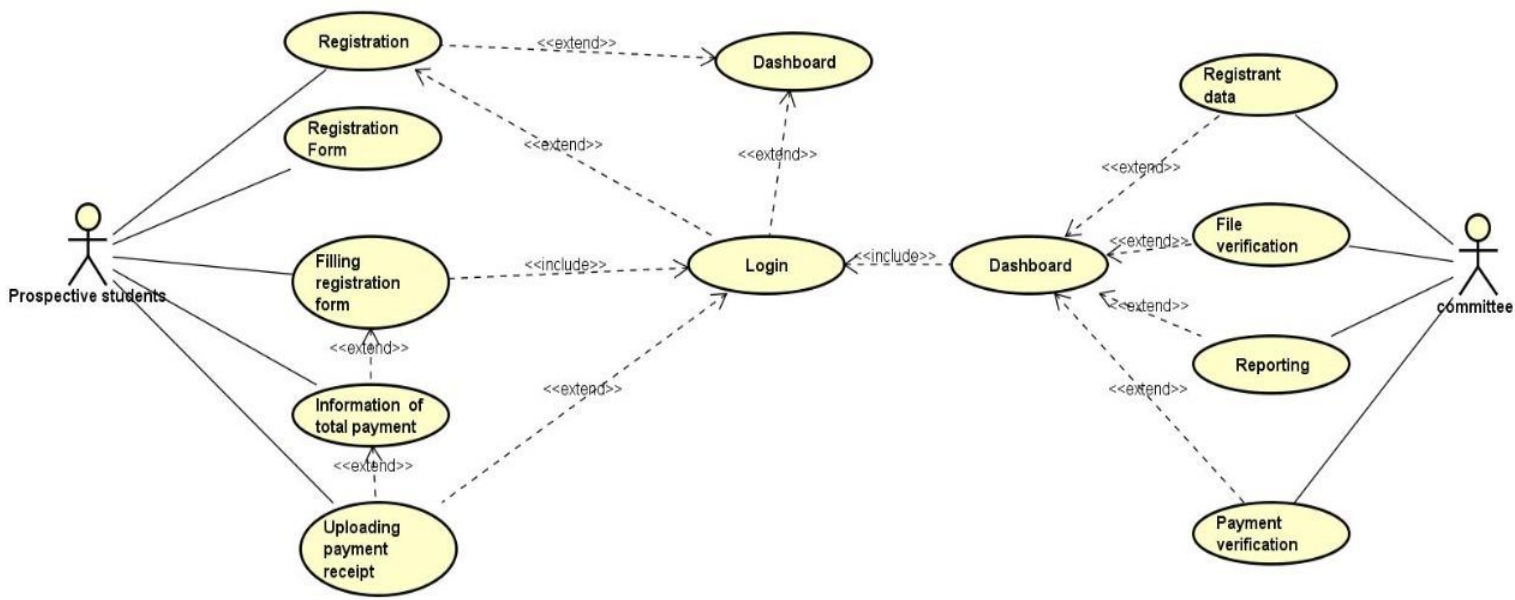

Figure 4. Use Case of New Student Admission

\section{b. Net Dashboard}

The author designs the teaching and learning process as shown in Figure 5. Net Dashboard will be used by students, teachers and vice principals of curriculum and industrial relations. Students will be able to access to do attendance before starting lessons, access modules, make chat interactions according to subjects, do evaluations both the mid test or final test, get detailed scores of all subjects followed while being a student, and get information about the latest job vacancies according to the department. The teacher has the task to fill in the module content, provide online material and prepare questions for the student evaluation process. The duty of the vice principal of 
curriculum is as an audit to see the performance of teachers and students. The duty of vice principal of industrial relations is to update the available job vacancies (See Figure 5).

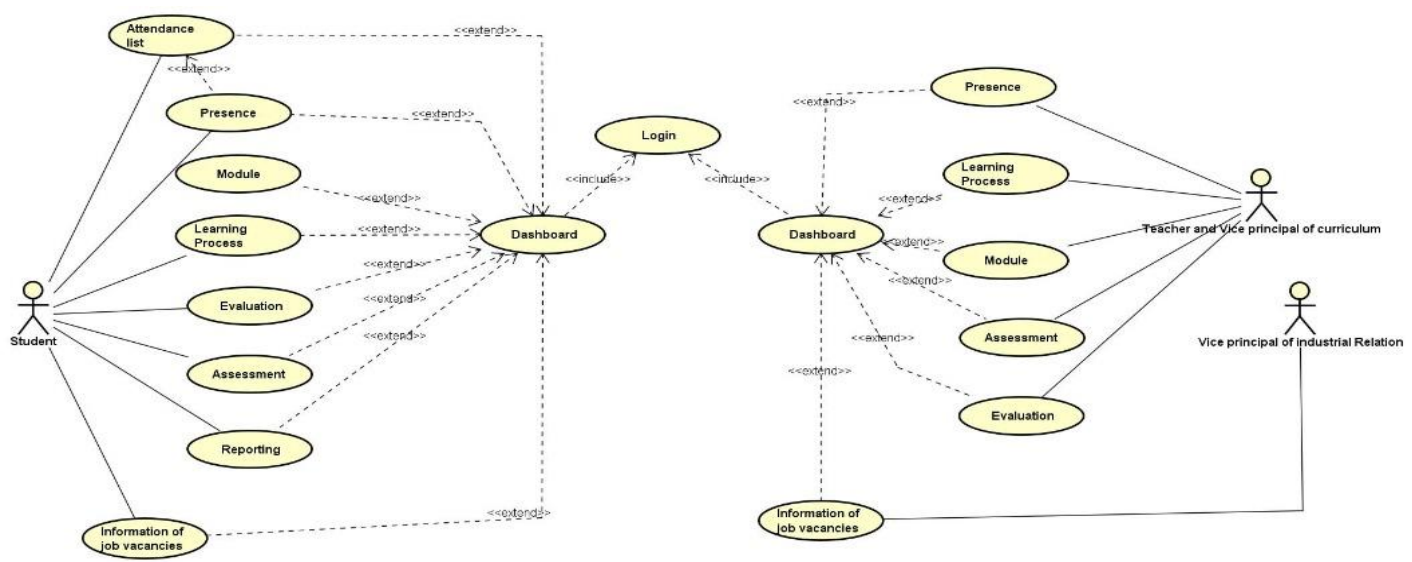

Figure 5. Use Case of Net Dashboard

c. Financial Management

The author designs the financial management process as shown in Figure 6. The financial department recapitulates financial management to be reported to the principal.

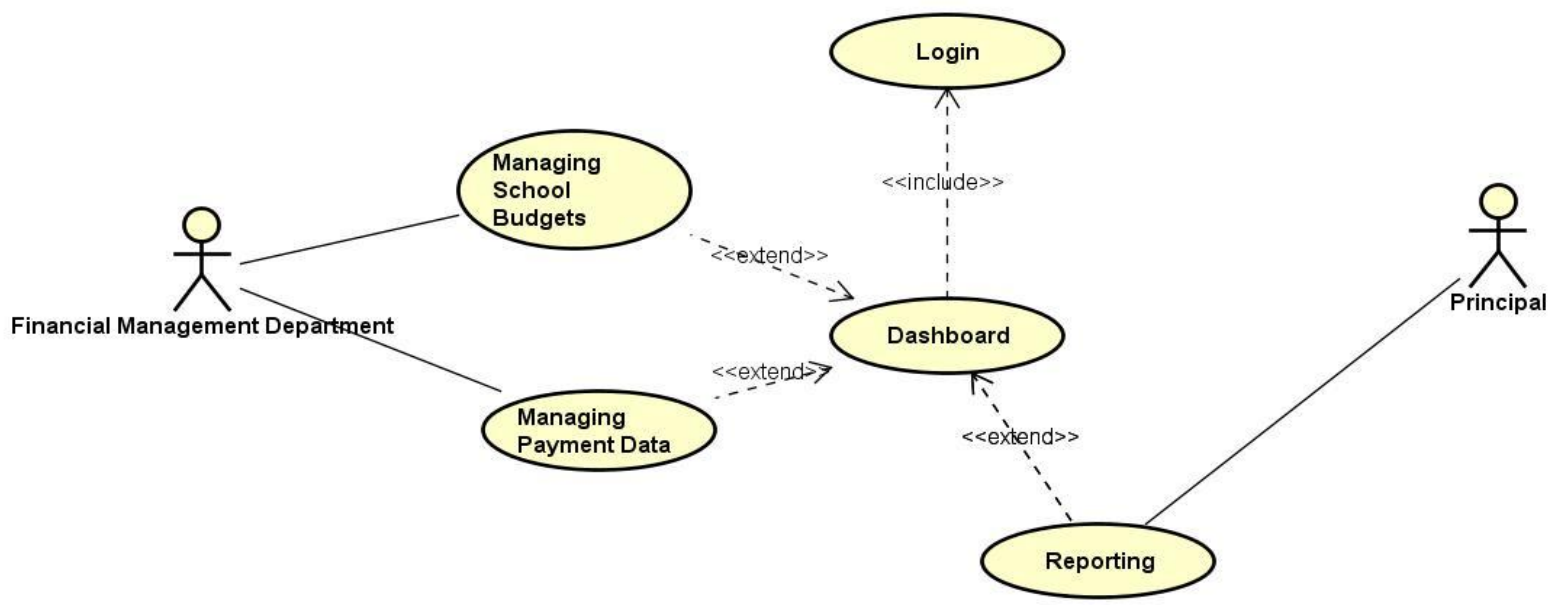

Figure 6. Use Case of Financial Management 
d. Resource Management

The author designs the resource management process as shown in Figure 7. The vice principal of infrastructure manages inventory data in the school environment and other required data. The vice principal of curriculum manages staffing data in the school environment.

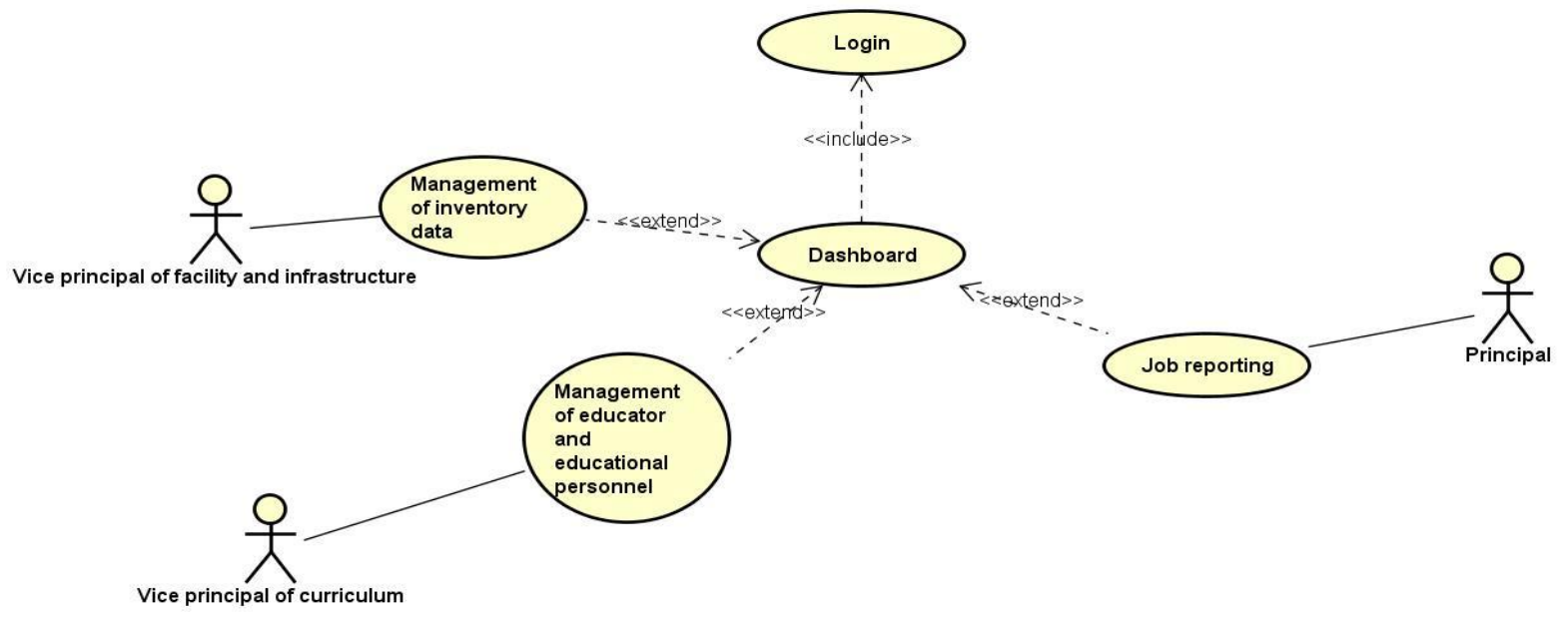

Figure 7. Use Case of resource management

\subsubsection{Success Factors of Application}

The essential things that must be considered to ensure the successful implementation of the enterprise architecture in accordance with organizational goals can be provided through determining the implementation success factor. The factors that determine the successful implementation of this system include:

a. Engagement, support and commitment from the management. Commitment from strong and consistent management as well as direct involvement will greatly help to accelerate implementation.

b. Availability of qualified and competent human resources in information technology. The organization needs to have qualified human resources in implementing enterprise architecture so that it does not always depend on the developer, especially for minor problems.

c. Developing a clear SOP (Standard Operations Procedure).

d. Having a roadmap for application and technology development to keep up with the latest developments. This means that the organization needs to be open-minded when there are new things that can be used to develop existing applications.

Based on the research results, several factors must be considered in the application process including:

The cost aspect is an economic factor of vocational high schools because it will require a lot of 
costs to implement this system. These costs are for the procurement of the device itself, both hardware devices and applications to be built, and other supporting infrastructure that needs attention.

The Human Resources aspect is the part that handles information technology and this should be handled by expert staff of information technology. Human resources who are directly or indirectly involved must be empowered both from information technology knowledge and operational knowledge of business processes so that all designs are right on target.

The aspect of overcoming system problems is taking action with a strict Quality Control process in the application modules prior to integration. Preparing proper, clear and complete documentation to anticipate problems so that it will be easier to conduct searches. Determining the priority scale for application development and the module creation process must be parallel for several modules that are related to the same priority scale.

\section{Conclusion}

Based on the discussion above and the implementation, it can be concluded that:

- Based on Porter's value chain model, business activities in the vocational high school environment are divided into two activities, namely main activities and supporting activities. The main activities consist of New Student Registration, Teaching and Learning Process, Student Graduation Process. Meanwhile, supporting activities consist of Financial Management, Resource Management, Research and Development.

- The utilization of Information Systems / Information Technology support in business processes can reduce business cycle times and increase efficiency and effectiveness.

- The development of application architecture found 4 major information systems needed to manage data and support the organization's business processes. The development priority is an Information System for students called Net Dashboard.

- The development of technology architecture proposes a conceptual enterprise network that allows data sharing and collaboration between business units.

- The model of the enterprise architecture that has been produced can be used as a first step to achieve the strategic goals of the organization and this can be used as a guide to direct information systems and information technology development policies to be more measurable and clear.

- The planning of enterprise architecture that has been built can serve as a guideline and direction for the development of information systems to support the organization's business strategy so that harmony is achieved between business strategies and information systems at information technology

\section{References}

Andayani, D. D. (2018). Application of the Prototype Development Model to Develop Online Information System for Student Internship at the Vocational High School in South Sulawesi Indonesia. Advanced 
Science Letters, 24(5), 3713-3717.

Attaran, M. (2004). Exploring the relationship between information technology and business process reengineering. Information \& management, 41(5), 585-596.

Gong, Y., Yang, J., and Shi, X. (2020). Towards a comprehensive understanding of digital transformation in government: Analysis of flexibility and enterprise architecture. Government Information Quarterly, 37(3), 101487.

Guthrie, H., and Clayton, B. (2010). Building Capability in Vocational Education and Training Providers: The TAFE Cut. Occasional Paper. National Centre for Vocational Education Research Ltd. PO Box 8288, Stational Arcade, Adelaide, SA 5000, Australia.

Hadiana, A. (2016). Perencanaan Arsitektur Enterprise Perguruan Tinggi Menggunakan Oracle Framework. Jurnal Teknologi \& Manajemen Informatika, 1(1), 1-7.

Kaplinsky, R. (2000). Globalisation and unequalisation: What can be learned from value chain analysis?. Journal of development studies, 37(2), 117-146.

Lakhrouit, J., and Baïna, K. (2020). Analysis and implementation of the impact of change: application to heterogeneity algorithms in enterprise architecture. International Journal of Electrical and Computer Engineering, 10(1), 377.

Moraes, T. K. L., and Cernev, A. K. (2020). OriginalMy: Blockchain technology and business defying a 20thcentury regulation. Journal of Information Technology Teaching Cases, 10(2), 108-118.

Ozer, M., and Perc, M. (2020). Dreams and realities of school tracking and vocational education. Palgrave Communications, 6(1), 1-7.

Rabiman, R., Nurtanto, M., and Kholifah, N. (2020). Design and Development E-Learning System by Learning Management System (LMS) in Vocational Education. Online Submission, 9(1), 1059-1063.

Sambas, A., Mada Sanjaya, W. S., and Mamat, M. (2013). Design and numerical simulation of unidirectional chaotic synchronization and its application in secure communication system. Journal of Engineering Science and Technology Review, 6(4), 66-73.

Samson, M., and Vergnaud, T. (2019, October). Automatic Generation of Test Oracles from Component Based Software Architectures. In IFIP International Conference on Testing Software and Systems (pp. 261-269). Springer, Cham.

Suswanto, H., Mursyidun Nidhom, A., Bagus Nur Rahma Putra, A., Saleh Ahmar, A., Smaragdina, A. A., Cahyono Putro, S., and Wibawanto, S. (2018, April). Development of Mobile Academic Exhibition Information System to Support Achievement of Job Hiring Graduate Vocational High School. In $J$. Phys. Conf. Ser (Vol. 1028, No. 1).

Wikusna, W. (2018). Enterprise architecture model for vocational high school. IJAIT (International Journal of Applied Information Technology), 2(01), 22-28.

Yulastri, A., and Hidayat, H. (2017). Developing an Entrepreneurship Module by Using Product-Based 
228 Muhammad P. A. Q. Saleh et al./ International Journal of Quantitative Research and Modeling, Vol 1, No 4, pp. 217-228, 2020

Learning Approach in Vocational Education. International Journal of Environmental and Science Education, 12(5), 1097-1109. 